\title{
Design ecologies: sustaining ethno-cultural significance of products through urban ecologies of creative practice
}

\author{
Stuart Walker $($ Douise Mullagh $\cdot$ Martyn Evans $\cdot$ Yanzhong Wang
}

Received: 16 October 2019 / Accepted: 13 November 2019 / Published online: 16 December 2019 (C) The Author(s). 2019 Open Access This article is distributed under the terms of the Creative Commons Attribution 4.0 International License (http://creativecommons.org/licenses/by/4.0/), which permits unrestricted use, distribution, and reproduction in any medium, provided you give appropriate credit to the original author(s) and the source, provide a link to the Creative Commons license, and indicate if changes were made.

\begin{abstract}
This paper presents an account of field research and its findings from an international knowledge exchange project entitled Design Ecologies: Sustaining ethno-cultural significance of products through urban ecologies of creative practice, jointly funded by the UK's Arts and Humanities Research Council (AHRC) and the Chinese Academy of Social Sciences (CASS), Beijing. The contribution of this paper is to effectively communicate the processes, mechanisms and benefits of an academic knowledge exchange programme. In this case, six exchange visits were carried out, three to China by the British team and three to the UK by the Chinese team. These visits offered opportunities for both teams to gain insights into a variety of heritage sites and craft practices, as well as to the wider policy landscapes in each country. We found that the use of certain terms, like 'creative industries', to refer to traditional craft practices and other heritage related activities can be problematic as they tend to emphasise their instrumental rather than their intrinsic value. The Chinese team found the importance and significance of
\end{abstract}

\section{S. Walker $(\bowtie)$}

ImaginationLancaster Design Research Centre, Faculty of Arts and Social Sciences, LICA Building, Lancaster University, Lancaster LA1 4YW, UK

e-mail: s.walker@lancaster.ac.uk

L. Mullagh · M. Evans

Manchester Metropolitan University, Manchester, UK

e-mail:1.mullagh@mmu.ac.uk

M. Evans

e-mail: martyn.evans@mmu.ac.uk

Y. Wang

Chinese Academy of Social Sciences, Beijing, China

e-mail: wangyzh@cass.org.cn 
volunteers within the UK's cultural heritage landscape to be very different from that of China, which does not have a history of volunteering. On the other hand, China supports its Intangible Cultural Heritage through adoption of the UNESCO Convention for the Safeguarding of the Intangible Cultural Heritage, hereafter referred to as the UNESCO Intangible Cultural Heritage (ICH) programme or UNESCO convention (UNESCO 2019b; Cominelli and Greffe 2012); in contrast, the UK has not ratified the UNESCO convention. The China team commented on the UK's approach to heritage that keeps a sense of 'living' heritage, e.g. The English Lake District is a UNESCO World Heritage Centre in which people still live and work. In China, such areas are often depopulated to preserve the heritage and focus on tourism. The British team identified opportunities for design contributions in the visualisation of interrelated and interdependent "ecosystems" of design and production, as observed in Jingdezhen Ceramics Factory. Also, at Taoxichuan Creative Zone design was already being used effectively for the design of artefacts, points of sale, branding and packaging. There is much potential for this to be explored and developed further with different case studies in the UK and China. A shared understanding was developed from the knowledge exchange visits and visit reports created by each of the respective teams. These led to a set of conclusions, insights and themes. Finally, this project has already paved the way for a further Arts and Humanities Research Council (AHRC) research project entitled Located Making, in collaboration with the Beijing Institute of Fashion Technology and Ningxia University.

Keywords Knowledge exchange $\cdot$ UK $\cdot$ China $\cdot$ Heritage $\cdot$ Craft $\cdot$ Policy

\section{Introduction}

In recent decades, government policies and corporate directions have leaned towards international cooperation and economic globalisation in the West, especially the US and Europe, and in China (Baldwin, 2019, pps.3-4; World Bank, 2008). These developments have had benefits in terms of economic growth, the fostering of international understanding, and the raising of material standards of living for millions. However, this has brought not only increased wealth but also, in China, rapid urbanisation and social upheaval due to people relocating to urban centres from rural villages ( $\mathrm{Wu}$ and $\mathrm{He}, 2018$, p.3300). These societal changes have affected the standing and significance of traditional ethno-cultural designs, material cultures, and heritage practices. With the increased availability of affordable, massproduced products, traditional artefacts have often become regarded as old fashioned and commercially uncompetitive and, consequently, have become sidelined. As a result, the traditional making-practices (i.e. the intangible cultural heritage) that enabled many of these artefacts to be produced have fallen into decline and, in some cases, have become lost, although, currently, efforts are being made to revive them as part of a rural tourist economy (Gao and Wu, 2017, pps. 223, 228-232). Often, these practices incorporate intergenerational, place-based knowledge about local materials and the cultural meanings of local designs (Jung and Walker, 2018 p.11). 
These developments are especially relevant in contemporary China because of its extremely rapid industrialisation and economic growth over recent decades.

This paper presents an account of field research and its findings from an international knowledge exchange project entitled Design Ecologies: Sustaining ethnocultural significance of products through urban ecologies of creative practice, jointly funded by the UK's Arts and Humanities Research Council (AHRC) and the Chinese Academy of Social Sciences (CASS), Beijing. The contribution of this paper is to effectively communicate the processes, mechanisms and benefits of an academic knowledge exchange programme. This particular knowledge exchange project involved academics from Lancaster University and Manchester Metropolitan University in the UK and CASS in Beijing. The aim was to develop an understanding of the ethno-cultural significance of products through urban ecologies of creative practice as found in China and the UK. For the purposes of this project, 'an urban ecology of creative practice', which we refer to as a 'Design Ecology' includes the variety of interrelated elements within a locale that enables a practitioner to be effective - it might include other practitioners as well as suppliers, markets, museums, policymakers, local resources etc. A Design Ecology can be used an analytical model that provides a comprehensive overview of the context in which maker enterprises operate. This concept was developed from empirical studies during our previous research and has been tested and further developed through international workshops (Jung and Walker, 2018, pps.11-24). The resultant overview, grounded in local examples of making, provides a basis for creating design recommendations and a strategy for identifying where and how design can make a constructive contribution to the future viability of these culturally important practices.

The three key project objectives of this field research were as follows:

a) Knowledge exchange - To develop knowledge exchange mechanisms between the UK and China for understanding the cultural significance of products through urban ecologies of creative practice;

b) Shared Understanding - Develop a shared understanding of the current condition and future potential, socially and economically, of culturally significant designs and products in relation to urban ecologies of creative practice;

c) Longer Term Collaboration - To develop further opportunities for institutional collaboration in researching the viability and future directions of culturally related industries in the UK and China, including the potential offered by digital technologies.

In this report, we describe the mechanisms developed to further this knowledge exchange, which include methods such as visits, interviews, observations, and expert presentations and discussions, as well as symposia for discussion and exchange of insights and ideas. This is followed by a presentation of the main findings, a discussion of these, and the development of conclusions and insights. From this, we draw out of some key themes, discuss directions for future research, 
and introduce a follow-on project resulting from this knowledge exchange opportunity.

\section{The Exchange Mechanism}

The exchange mechanism took the form of a series of three visits by UK researchers to China, and three visits by Chinese researchers to the UK. Each visit was tailored by the host group to address the specific areas of interest of the visiting group. Chinese participants were from the Department of Anthropology and Ethnology at the Chinese Academy of Social Sciences in Beijing. Their research interests were in heritage, urban development and policy. Participants in the UK were from Imagination Design Research Lab at Lancaster University and the Department of Design at Manchester Metropolitan University. They had a design background with research interests in product design and in the designs, makingpractices, functions and cultural meanings of traditional artefacts.

Visits were developed by both teams, with the host team offering advice as to relevant sites and enterprises, in addition to organising meetings with key representatives and academic symposia. During each visit (see Table 1 for details) the teams carried out empirical research through interviews and observations of makers, guided tours led by experts in the field, symposia and meetings with academics and policy professionals. The qualitative data from the research visits, in the form of field notes, recorded interviews, and photographs were then used as the basis from which insights and key conclusions were made by each team. For each visit one team produced a report, including information and images from the visit, insights and conclusions, from which overall conclusions were developed. The reports were circulated between both teams, who commented and added further insights and conclusions. This process enabled each team to see their own country differently, through the reflections provided by the visiting team.

\section{The Development of a Shared Understanding}

A common understanding was developed from the knowledge exchange visits and the visit reports created by each of the respective teams. It consists of a set of conclusions, insights and themes. These became evident through discussions between British and Chinese participants, which identified similarities and, in some cases, very significant differences between understandings of and approaches to heritage practices and places in China and the UK.

For the Chinese delegation, their first UK visit was to significant heritage sites of the British Industrial Revolution around Manchester and Liverpool, both of which experienced rapid urban development in the nineteenth century. The second visits looked at cultural reactions and responses to these rapid industrial developments, in the form of British Romanticism, the centre of which was the nearby English Lake District. Visits were arranged to National Parks and significant locations, many of which are now run by the National Trust. The third and final visit was to the national headquarters of heritage-related organisations and national heritage archives in Swindon and London. 
Table 1 Design Ecologies Knowledge Exchange Visits

\begin{tabular}{|c|c|}
\hline Location and Year & Visits and Activities \\
\hline \multirow[t]{3}{*}{ Shanghai 2016} & $\begin{array}{l}\text { Symposium: Project Goals; Research Interests; } \\
\text { Planning and Implementation in Sichuan; } \\
\text { Protection of Woodblock Printing; Shanghai } \\
\text { Cultural Heritage Industry; Cultural Industry in } \\
\text { China }\end{array}$ \\
\hline & $\begin{array}{l}\text { Visits: Huang Daopo Memorial and Museum; } \\
\text { Shanghai Museum of Arts and Crafts; } \\
\text { Tianzifang Area; Nanjing Road West - Old } \\
\text { Brands; Shanghai Silk Group Company; M50 }\end{array}$ \\
\hline & Output: Report by UK Team \\
\hline \multirow[t]{3}{*}{$\begin{array}{l}\text { Manchester \& } \\
\text { Liverpool } 2016\end{array}$} & $\begin{array}{l}\text { Meeting: Manchester Metropolitan University; } \\
\text { Arts Council }\end{array}$ \\
\hline & $\begin{array}{l}\text { Visits: Special collection exhibition at MMU; } \\
\text { Quarry Bank Mill; Walking Tour of } \\
\text { Manchester; International Slavery Museum, } \\
\text { Liverpool; The Cavern Club, Liverpool }\end{array}$ \\
\hline & Output: Report by the China team \\
\hline \multirow[t]{3}{*}{$\begin{array}{l}\text { Hangzhou \& } \\
\text { Jingdezhen } 2017\end{array}$} & $\begin{array}{l}\text { Symposium: Cultural Heritage and Cultural } \\
\text { Identity, Zhejiang University }\end{array}$ \\
\hline & $\begin{array}{l}\text { Visits: Zhufu Grand Copper Store \& Museum; } \\
\text { Lang Ling Fashion Company (Opera } \\
\text { Costumes); Hangzhou Arts \& Crafts Museum; } \\
\text { Taoxichuan 'Creative Zone' Jingdezhen; Mr. } \\
\text { Sun Ceramics Studio; Pottery Workshop } \\
\text { Creative Market Area; Jingdezhen Heritage of } \\
\text { Ceramics Museum; Zhu Legeng Ceramics; } \\
\text { Jingdezhen China Ceramics Museum }\end{array}$ \\
\hline & Output: Report by UK team \\
\hline \multirow[t]{3}{*}{$\begin{array}{l}\text { Lake District, } \\
\text { Cumbria } 2017\end{array}$} & $\begin{array}{l}\text { Meeting: Imagination Lab, Lancaster } \\
\text { University }\end{array}$ \\
\hline & $\begin{array}{l}\text { Visits: Dove Cottage; Wordsworth Museum, } \\
\text { Grasmere }\end{array}$ \\
\hline & Output: Report by China team \\
\hline \multirow[t]{2}{*}{$\begin{array}{l}\text { London \& Swindon } \\
2018\end{array}$} & $\begin{array}{l}\text { Visits: Historic England, National Trust, } \\
\text { Heritage Alliance }\end{array}$ \\
\hline & Output: Report by China team \\
\hline \multirow[t]{2}{*}{ Beijing 2019} & $\begin{array}{l}\text { Symposium: Cultural Heritage, Cultural } \\
\text { Creativity and Cultural Industries. Public open } \\
\text { forum at CASS }\end{array}$ \\
\hline & $\begin{array}{l}\text { Visits: Shougang Creative Industries Park, } \\
\text { Beijing Enamel Factory Co.; } 798 \text { Creative } \\
\text { Industries Zone }\end{array}$ \\
\hline
\end{tabular}

In China, the UK team visited sites of making-practices and related cultural significance, including museums, art galleries, maker collectives, and government-sponsored heritage sites in Shanghai, Hangzhou and Jingdezhen, and in Beijing. During all these visits, the British team observed, photographed, heard expert presentations, conducted key-informant interviews and benefited from expert tours. 
For each visit, a report was produced by the visiting team that documented their visit and developed a series of conclusions and key insights.

Within these overall project objectives, the UK and China teams each had a somewhat different focus. For Chinese participants, the objectives were to obtain a better understanding of the following aspects of British heritage and areas of historic, national, and international cultural importance:

- how they are preserved and cared for;

- how they are financed;

- how they contribute to a thriving contemporary culture and tourist industry; and

- how the UK ensures the sustainment of its tangible and intangible cultural heritage into the future.

The UK team had two primary objectives relating to traditional makingpractices and cultural heritage:

- to understand how traditional making-practices are valued, affirmed and sustained through visits to different locations and different enterprises in China;

- to understand how China's intangible cultural heritage is documented and actively embraced and sustained, alongside China's very significant economic development and commitment to technological innovation and to becoming a major presence in the global economy.

\section{Summary of Visits to China 2016-2019}

\section{Shanghai, July 2016}

Shanghai was chosen for the UK team's first visit to China because of its rich heritage of creative practices, including both its traditional craft practices and its more contemporary interpretations of heritage crafts. The city is home to various 'Old Brand' stores, which demonstrate China's commitment to the revival of traditional products. In 2006 the Ministry of Commerce initiated "The Project of Revitalizing Chinese Old Brand Enterprises" of which more than 10,000 companies have been identified throughout the country.

The programme began with the UK and Chinese teams discussing their particular approaches to research and each showed examples of their project work. In particular, the UK team presented their previous AHRC Design Routes project (Gateway to Research 2019) that explored culturally significant designs, products and practices, and resulted in the book DESIGN ROOTS (Walker et al., 2018). The Chinese team's presentations included China's Old Brands, the curatorial programme for Shanghai Cultural Protection, the cultural industry in China, and case studies that demonstrate the planning and implementation of heritage and cultural policy in the country.

Site visits around Shanghai were programmed to offer insights into various types of products made in the city as well as a number of relevant museums. The 
Huang Daopo Memorial and Museum (Fig. 1 Huang Daopo Memorial and Museum) is dedicated to the work and contribution of Huang Daopo, a pioneer and innovator in the textile industry during the thirteenth century. She brought advanced techniques of spinning from Hainan to her hometown of Songjiang and made various innovations in the development of textile tools and the practice of spinning. Her work promoted the textile industry within China and beyond and contributed to the social and economic prosperity of the period.

This visit offered insights into the development of museums in China, which are seen as key to promoting cultural heritage and craft practices. This is an important area for the government in terms of cultural heritage and tourism, in addition to its focus on intangible cultural heritage. The UK team learned that China enthusiastically participates in the UNESCO Intangible Cultural Heritage programme, which, importantly, includes opportunities for people to learn traditional practices. This sustainment of the practice is fundamental to the UNESCO $\mathrm{ICH}$ programme. At the Huang Daopo Museum, a room had been set aside as a classroom-training facility, which housed a large number of refurbished traditional spinning wheels as well as two refurbished hand looms.

A visit to the Tianzifang Area offered insights into the development of a cultural area that now houses fashionable bars, restaurants and shops. This was originally a residential area that was saved from high-rise development and repurposed to attract young residents and tourists (Fig. 2 Tianzifang, Shanghai). When first redeveloped, it was home to many small crafts and arts enterprises. Today, however, due to its success in attracting tourists, rents have increased. There are now many more shops, bars and food outlets, while many of the small crafts and arts enterprises have moved out.

Fig. 1 Huang Daopo Memorial and Museum

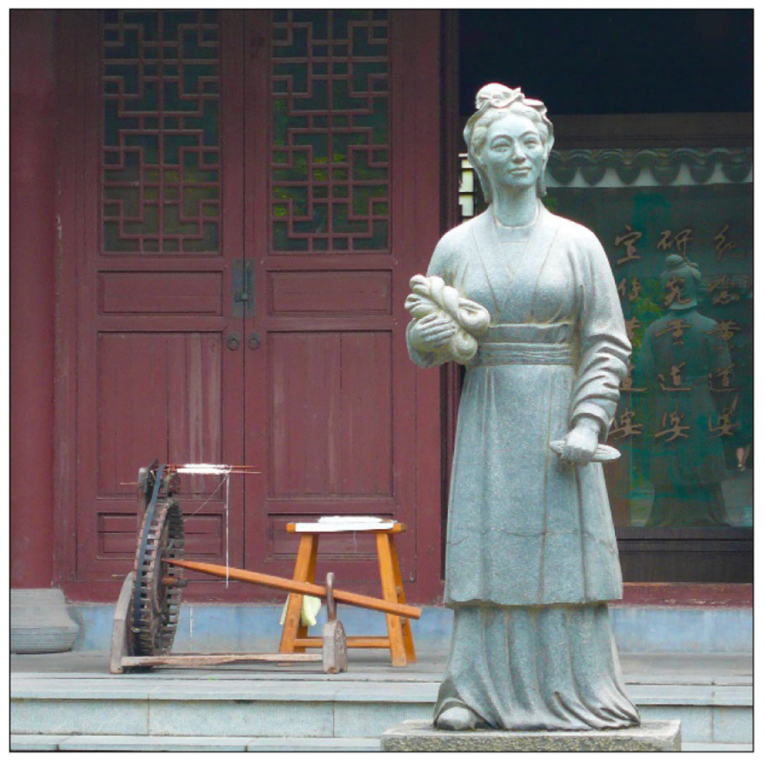




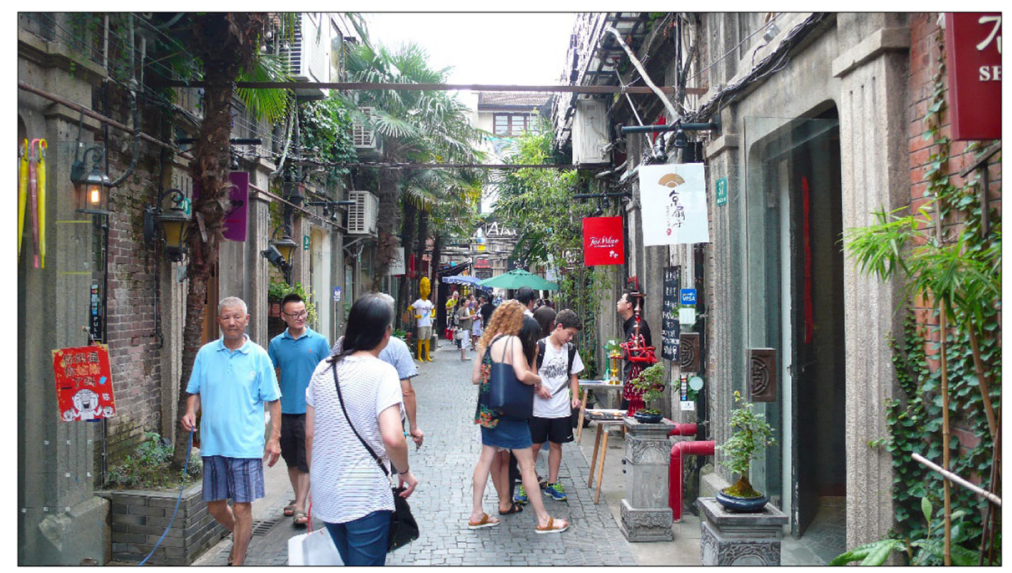

Fig. 2 Tianzifang, Shanghai

The Shanghai Silk Group Company produces double-sided silk embroidery, which is a highly skilled and very time-consuming practice. The company also produces fine, high-quality silk weaving of traditional pictures and it weaves the lettering in silk books using sophisticated digital weaving techniques. Such items are very expensive and are given as gifts to royalty and visiting dignitaries (Fig. 3 Silk Book, The Shanghai Silk Group Company). This visit demonstrated how traditional craft is being sustained in China not only by continuing traditional methods but also by embracing new technologies. In addition, this company was also making medical products from 3D woven silk.

M50 is now a cultural zone that was once the site of various factory buildings. The area developed as artists moved into the district, attracted by the cheap rents available in this old industrial area. Today, M50 is home to over 100 artists' studios, galleries, design agencies and other cultural enterprises, and is a major tourist attraction in the city (Fig. 4 Bamboo Weaving over Porcelain, M50 Creative Park, Shanghai).

Fig. 3 Silk Book, The Shanghai Silk Group Company

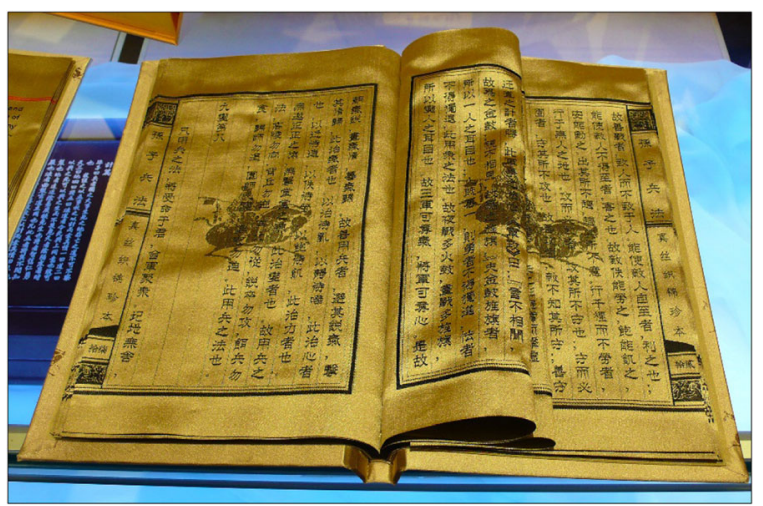


Fig. 4 Bamboo Weaving over Porcelain, M50 Creative Park, Shanghai

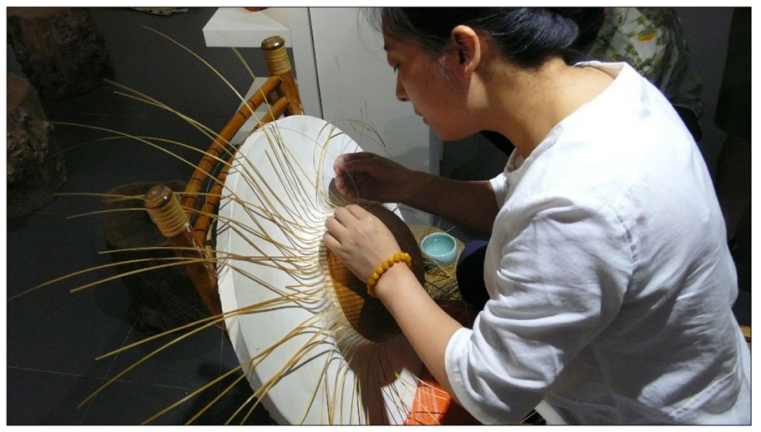

\section{Hangzhou and Jingdezhen, September 2017}

This visit began with a symposium on Cultural Heritage and Cultural Identity at Zhejiang University, in Hangzhou. The UK team introduced the project to academics and curatorial staff from nearby museums. Presentations by Chinese participants introduced the crafts of Hangzhou and the work being done at the museums to sustain traditional practices such as silk umbrella making, woodcarving and kite making. The curator of a Hangzhou museum highlighted the impact the Chinese government's focus on intangible cultural heritage is having, especially in increasing people's awareness of traditional crafts and the importance of communicating their value and importance to the public. The importance of tourism in China was also highlighted, where the Gross Domestic Product (GDP) of cultural and creative industries makes up 25\% of the overall GDP of Hangzhou and accounts for some 250 billion RMB in revenue. The significance of tourism to the area has led to space being offered for cultural and creative industries, with more than 300 buildings over 50 years old being preserved, the development of cultural heritage applications and techniques within the animation industry, and making use of cultural heritage through its incorporation into the production of everyday products.

Visits to shops and craftspeople in Hangzhou enabled the UK team to gain insights into the local crafts and speak to a variety of makers. These included the Grand Copper store, which also contains a museum, and the Chinese Art Fashion Company, which is renowned for its Chinese opera costumes. Lang Ling, the owner of the company employs 40 staff and has won numerous awards for her costume designs. The company works with various enterprises to design costumes for online games and conducts research into the development of colours and trends. Lang Ling also designed the costumes for the Chinese teams when China hosted the Olympics in 2008.

The curator of the Hangzhou Arts and Crafts Museum introduced the museum's four specialised collections: Knives, Scissors and Swords; Umbrellas; Fans; and The Workmanship Demonstration Pavilion. The museum also holds a large collection of other arts and crafts, which include ceramics, wood and stone carving, embroidery, and weaving. The Pavilion houses a range of traditional crafts with works by more than twenty master makers featured. Here, the public can view the crafts in close proximity. It is also where apprentices are taught. Government 
investment provides a number of studios and spaces for artisans and a strong base for the preservation, sustainment and communication of traditional handcrafts by experienced masters, many of whom have been awarded regional or national intangible cultural heritage status. Visitors can look around studios, try out crafts, watch craftspeople at work and speak directly to them (Fig. 5 Parasol Making, Hangzhou Arts and Crafts Museum). It is well organised with detailed information boards in both Chinese and English. Alongside artisan studios, a more traditional museum covers key arts and crafts from the region.

The visit to Jingdezhen included the Taoxichuan 'Creative Zone', a ceramics studio, pottery workshop market area and a ceramics museum. The ceramics industry in Jingdezhen has long been central to the economic and cultural prosperity of the city. In recent times, old government-owned ceramics factories having been redeveloped and repurposed into museums and creative zones. Taoxichuan 'Creative Zone' is one such example and is a major a creative hub. It has been transformed from a former ceramics factory site through investment from the local government and now receives between 7000 and 10,000 visitors a day, and includes galleries, cafés, restaurants, museums and the JDZ Youth Zone. The latter, on the site of the old kilns, which are still visible, is a collection of individual artisan stores/stalls under one roof. The products on sale are generally contemporary in nature, but respectful of traditions without being constrained by or tied to the past. Some artisans have employed contemporary design not only in the artefacts they produce but also in their packaging, branding, etc. The JDZ Youth Zone offers an affordable way for young craftspeople to sell their products in a venue that has high foot traffic due to its juxtaposition with other facilities - galleries, cafés, a bar and a hotel. The JDZ Youth Zone also serves to affirm the importance of craft practices to young people.

Jingdezhen is also home to many ceramics masters and enterprises, one of which is Mr. Sun's studio. Mr. Sun has worked in the ceramics industry since 1976. At the age of 16 he started working in one of the large government factories before becoming an independent artist. The factory in which he worked was the only one in China to produced ceramic artworks, so workers needed artistic skills

Fig. 5 Parasol Making,

Hangzhou Arts and Crafts Museum

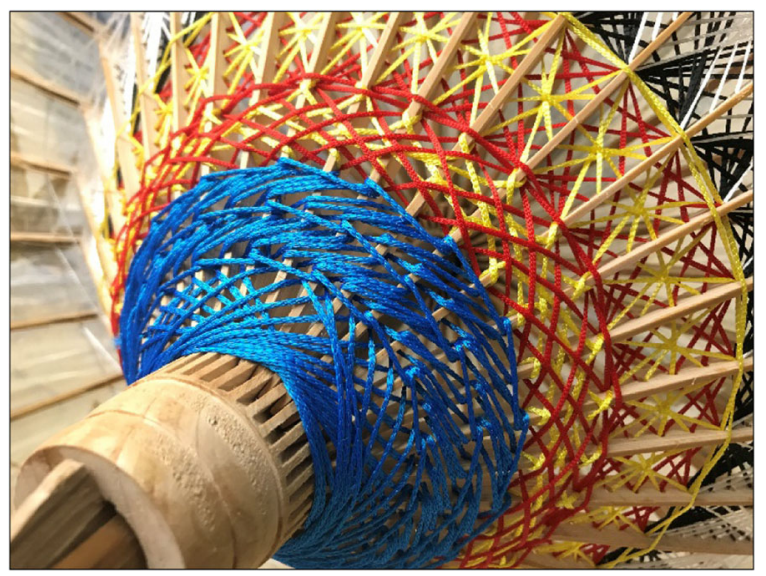


to decorate the ceramics. In factories that produced more utilitarian artefacts the work was generally less skilled. His factory originally employed 500 workers, and when it closed approximately 200 former employees set up their own independent enterprises. Since setting up on his own, Mr. Sun feels he has had more freedom to change his designs and is able to better respond to market demands. His artwork is now simpler and primarily driven by his own style. He generally employs 5-6 people, more at busy times. He is regarded as the master and he trains his employees. He also trains apprentices who, when they complete their training, usually set up their own businesses. There is a distinct division of labour between specialist experts in the production process, with the master creating the designs and carrying out the more intricate tasks. Mr. Sun's inspiration comes from books, television, archaeological sites etc. Some of his designs are based on traditional characters that have cultural relevance and links to tradition. In others, he explores more contemporary themes.

Close to Mr. Sun's studio, which is in an older district of Jingdezhen, there is a network of other small enterprises, which appear to have grown organically over time. This has resulted in an intricate set of interrelated businesses and streets that have a traditional atmosphere. There is a concentration of specialist activities such as specialist mould makers, slip casters and kiln operators. Hence, in this area, there are master craft studios, production workshops, retail outlets, and a market area where students sell their work. This 'mixed economy' provides a vibrant, if somewhat chaotic, feel.

The Jingdezhen Heritage of Ceramics Industry Museum - The Imperial Kiln Site of Jingdezhen is designated by UNESCO and comprises a 'living museum' experience where experienced craftspeople in traditional dress demonstrate all aspects of the production of porcelain using heritage techniques (Fig. 6 Jingdezhen Heritage of Ceramics Industry Museum). These practices are faithfully adhered to and a high degree of skill is in evidence in the largely aging workforce. The process employs a division of labour where individual tasks are conducted by specialists. Collectively, these result in the

Fig. 6 Jingdezhen Heritage of Ceramics Industry Museum

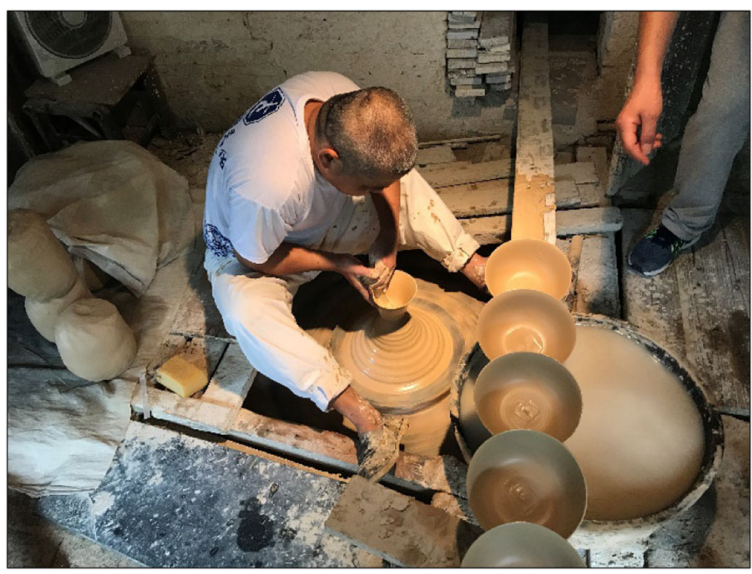


production of hand-decorated porcelain products. Visitors are able to watch and speak to the makers as they practise their particular specialism.

Professor Zhu runs the Zhu Legeng Ceramics Studio at the Chinese National Academy of Arts. He develops and produces a range of innovative and large-scale art ceramics (Fig. 7 Zhu Legeng Ceramics Studio, Jingdezhen). The studio employs a number of assistants who work on both commissioned and self-directed pieces. Organised across a number of floors, the studio also acts as a museum, gallery, and factory, all of which support the development of innovative ceramics. As the studio is linked to the Chinese National Academy of Arts, there is a strong research component. The products demonstrate innovation in their concepts through the exploration of scale, ambition and decorative finish. Professor Zhu is a well-known ceramicist who has integrated this research-led approach with commercial enterprise. Many of the products produced in his studio are sold around the world and command high prices.

\section{Beijing, March 2019}

The visit to Beijing included a selection of factories and cultural heritage sites, a symposium on cultural heritage, cultural creativity and cultural industries, and discussion of the outputs of the project.

Shougang Park, and nearby Shijing Mountain Temple, is a key site of contemporary cultural heritage. It is a very large redevelopment project at the site of the former Shougang Iron and Steel Works (Fig. 8 Shougang Park Regeneration Site, Beijing). The steelworks closed in 2010 and the site has redeveloped as the home of the Winter Olympic 2022 Organising Committee and the site for several Olympic events. There is also the Museum of Regeneration of Shougang \#3 Blast Furnace, and an exhibition centre.

This redevelopment came about in part through President Xi Jinping's desire to reduce air pollution in Beijing. The steelworks has been relocated on the coast. This change of use from industrial to cultural is on a vast scale, with a large number of the old factory buildings being used for new purposes;

Fig. 7 Zhu Legeng Ceramics Studio, Jingdezhen

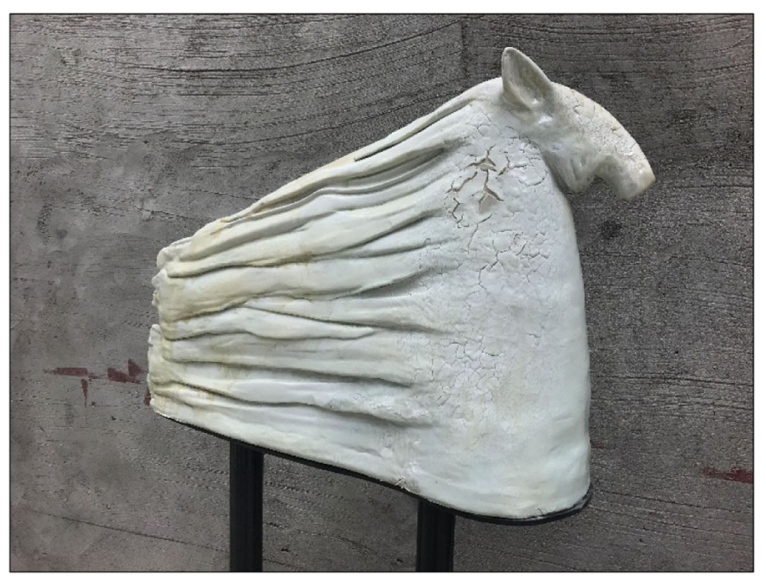




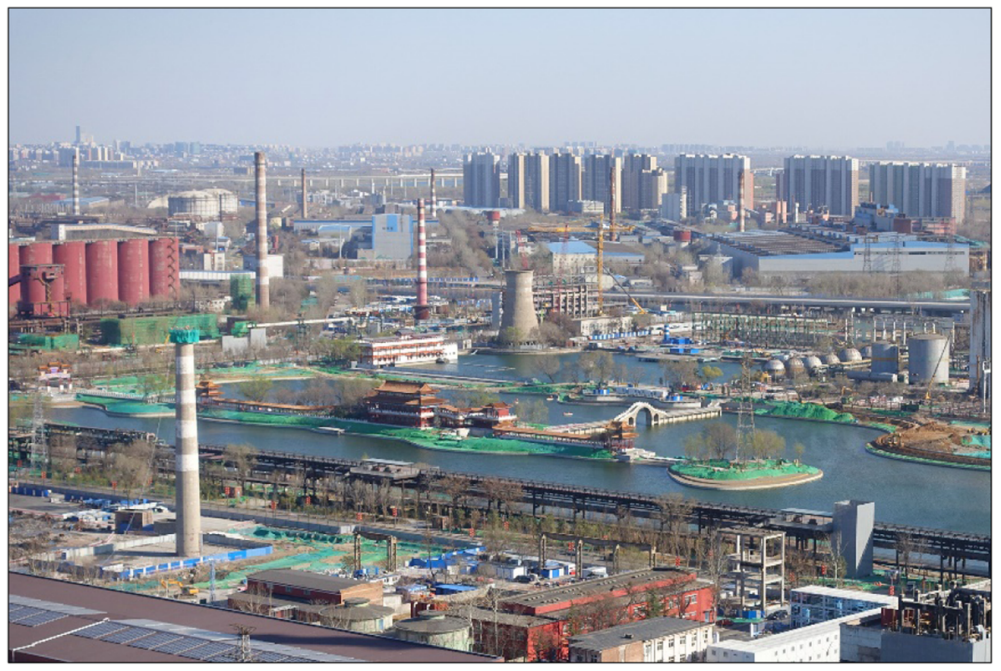

Fig. 8 Shougang Park Regeneration Site, Beijing

this again demonstrates the importance of the cultural heritage sector in China. Similar examples of industrial site repurposing in the UK are not on the same scale as Shougang. Often, such large sites would be partially or wholly demolished, perhaps with key buildings being retained and showcased, but at Shougang a great many buildings and much of the industrial infrastructure have been retained. Examples in the UK of such transformative use include old mills and power stations that have been re-purposed into cultural institutions, such as the Baltic Flour Mill in the Northeast (Baltic 2019) and Tate Modern in London (Tate Gallery 2019), both of which are now internationally renowned art galleries. In the former South Wales steel town of Ebbw Vale, however, the steelworks, which was on a similar scale as Shougang, was entirely removed and the valley floor was rebuilt with new facilities such as a hospital, leisure centre and educational facilities.

A workshop on cultural heritage, creativity, and the cultural industries held at the Chinese Academy of Social Sciences (CASS) offered a broad range of heritage policy- and practice-related presentations. Academics from the Chinese Academy of Cultural Heritage, Institute of Ethnology and Anthropology at CASS and the Research Centre of Artistic Anthropology presented on subjects relating to ceramics production in Jingdezhen, antiquities and heritage, heritage trends and indexes and traditional Chinese enamelware. These highlighted the importance of the UNESCO Intangible Cultural Heritage programme to China, particularly in terms of the development of their tourism market. Issues relating to the difficult balance between preserving traditional practices whilst ensuring that products be relevant to contemporary audiences were discussed, especially in relation to ceramic production in Jingdezhen. This is an area the UK team are exploring in their research in the region of Cumbria, England (Gateway to Research 2019). 
The following key differences in policy approaches between the UK and China were foregrounded:

- the importance of the UNESCO Intangible Cultural Heritage programme to China;

- the tendency of the Chinese government to drive policy and run cultural heritage organisations;

- the fact that many UK organisations are driven by 'bottom up' initiatives;

- the reliance of many UK heritage organisations upon funding sources other than the government e.g. National Trust memberships fees, and on volunteering (see London and Swindon Visit, 2018, below).

At the Beijing Enamel Factory Co. Ltd. the teams witnessed all the steps of the enamelware making process and had a chance to practise colour decoration of small enamel plates. The factory, founded in 1956, is the largest enamelware factory in China, and the only one that produces the Jingfa brand, classified under the 'Time Honoured Brand' scheme (Zhang 2019). Enamelware making is a wellestablished craft in China, although the techniques were introduced from the West. For many centuries, enamelware was produced only for the Chinese royal family. The peak period of production was during the Ming Dynasty (1368-1644) during which the most elaborate and highly valued pieces were produced. By the nineteenth century the quality of enamelware and the skills required were in decline, with few historic factories remaining. However, in the twentieth century craftspeople began making products for a wider audience and the craft recovered. Many pieces are now exported internationally and are also given as gifts by the Chinese government. The intricacy of the process makes the larger pieces very expensive (Fig. 9 Beijing Enamel Factory Co. Ltd.).

The factory receives many orders annually from private customers, government agencies and corporate institutions. They also produce pieces for exhibitions, both nationally and internationally, and have won awards for their work. However, most of their income is generated from the smaller products sold to the public and

Fig. 9 Beijing Enamel Factory Co. Ltd.

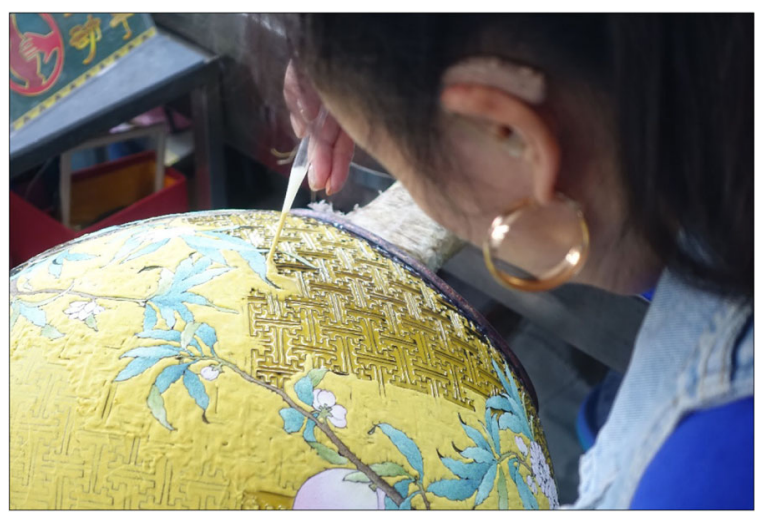


private collectors. Fewer than 100 people work in the factory. The master creates the intricate designs and each staff member has a specific, highly skilled task. This mirrors the distributed nature of production seen in the ceramics workshops in Jingdezhen, but in this case it is all under one roof.

The factory also incorporates a showroom, where customers can place orders and purchase goods, as well as a museum that features the history of enamelware and significant pieces produced in the factory. We have found this approach in a variety of visits during this exchange, which tends to be rare in the UK, one example being the Wedgwood factory and visitor centre, known as the "World of Wedgwood' in Stoke on Trent (World of Wedgwood 2019). In the enamelware museum we were shown contemporary pieces that used modern motifs, some of which were pared down and simple, and based on Western or Islamic motifs. These pieces were being made specifically for export, but they still echoed the traditional forms and techniques of decoration. The factory is also commissioned to create pieces for interior architectural details, such as decorative ceiling panels and pillars. The majority of pieces were vases and decorative objects, but more recently the technique has been applied to more functional objects such as lamps, which were still highly decorative and employed traditional, brightly coloured motifs. From a design perspective, some of these more contemporary designs seemed somewhat showy and/or kitsch to a Western eye.

\section{Key Insights from the UK Team Exchange Visits to China}

One key insight for the UK team was the concept and importance of Chinese Old Brands, which can include traditional making-practices, but also longestablished retail outlets. We also learned that China participates in the UNESCO $\mathrm{ICH}$ programme, a programme that we were not previously aware of, as the UK is not a participant (UNESCO 2019b; UK Government 2017). It also became evident that China is making considerable investments into its cultural heritage for cultural tourism, particularly internal tourism, by creating a large number of new museums and heritage centres. The approach to this, however, is rather different from that in the UK. In China, existing residents in an area of cultural value may be re-housed in an adjoining district so that the area can be better preserved as a cultural site. Professionally trained interpretive staff are then employed to serve the needs of visitors (Wang 2012).

The UK team also saw that efforts are being made to sustain traditional practices not only through the UNESCO ICH programme, but also in the commercial sector by producing high-quality goods. Moreover, the introduction and use of digital methods are becoming embraced in these practices with few apparent barriers to the use of technology to sustain and advance cultural traditions; for example we saw pattern making for silk weaving being done by highly skilled staff using computer applications and the creation of very fine silk embroidery using digital techniques. We also saw, as is often the case in the UK and elsewhere, that artists and craftspeople will move into low-rent, former industrial or other low-cost areas, but as their contributions stimulate tourism, rents increase and the artists and 
craftspeople subsequently move out, changing the nature of the district into primarily a venue for retail and tourism.

It became clear during our visit to Hangzhou that in China, tourism, including domestic tourism, can be a very important aspect of a local economy; in this case contributing some $25 \%$ of the overall GDP of the city. It is therefore understandable that China is making such efforts to invest in and promote its cultural heritage. It is sustaining traditions, history and culture, and this is being done in economically viable ways. During this visit we saw another example of how traditional crafts are merging with and embracing contemporary needs and sensibilities - costume designers who conventionally work in Chinese opera are now creating costumes for online games. This not only reveals an ability for the crafts to remain relevant to a contemporary audience, but also demonstrates that there are perhaps looser bonds between craft and the past than is often evident in other places. This willingness to engage with contemporary culture can help overcome perceptions of craft as being backward-looking and nostalgic.

While museums may provide studio spaces for craftspeople, which effectively subsidises their practice, this can also mean that craftspeople may be regarded as part of the museum display, which raises questions about the role and perceptions of craft, as well as ethical issues. However, similar 'living museums' are found elsewhere, including the UK. One example is the St Fagans National Museum of History (St Fagans 2019). The museum in Hangzhou also enabled apprentices to be taught the practices in order to ensure the continuity of the crafts.

In Jingdezhen there was another example of regional investment to create a cultural zone from former industrial factories, which attracts thousands of visitors and provides gallery and retail spaces for contemporary craftspeople, including young, up-and-coming ceramicists. It was again evident from the ceramic work in Jingdezhen that contemporary sensibilities and needs are being embraced by the traditional crafts to keep them relevant and desirable. Employees at former government-owned factories now run private craft enterprises in which they employ and train staff as well as apprentices who, once they have completed their studies with a master craftsperson, set up their own businesses. The move from state-owned factories to private-sector businesses has enabled crafts people to have more freedom in the kinds of work they produce and has led to a vibrant, if sometimes rather chaotic, mixed economy comprising studios, galleries, shops and markets. Traditional ceramics are not only being sustained through museums and 'living museums', but also through practising artists who are conducting research-through-practice within a university setting.

It is clear that China is making very significant government-funded investment in the cultural and tourist industries, even to the point of re-purposing very largescale former industrial sites (e.g. Shougang) for contemporary activities. This occurs at a grander scale than is evident in other places. The Beijing visit also reinforced our understandings of the commitment of China to the UNESCO Intangible Cultural Heritage programme and its importance to the country. It also became evident that development initiatives tend to be driven by the government in a topdown manner which contrasts with many of the heritage development initiatives and heritage conservation organisations in the UK, which often have their beginnings in grassroots, bottom-up initiatives and that rely on public support though 
membership fees and volunteering. Indeed, the importance of volunteering to sustain heritage sites in the UK was surprising to the Chinese team, who noted that this is not something that is prevalent in the Chinese context. The combination of fabrication, product showroom and craft museum within the private enterprise sector in China is very evident. This was the case for a number of the larger-scale craft enterprises we visited, such as the enamelware factory in Beijing (Fig. 10 The Cloisonné Art Museum of China, Beijing Enamel Factory Co. Ltd.).

Some of the traditional craft techniques are being used in ways that incorporate more contemporary designs and techniques, and the results can seem unsympathetic to their origins; sometimes there appears to be somewhat of a clash between very highly skilled techniques and the resulting designs, which to a Western eye, can occasionally seem rather kitsch. However, this contrasts markedly with the contemporary ceramic designs we saw in Jingdezhen where traditional techniques are being used to create high-quality, well-considered and aesthetically pleasing contemporary ceramic pieces that would suit an international market.

\section{Summary Visits to the UK 2016-2019}

\section{Manchester and Liverpool, July 2016}

The locations of the first visit to the UK by the Chinese team were key sites of the Industrial Revolution in the north of England and museums that highlight specific collections relating to social history.

The north of England played a major role in the Industrial Revolution (Ashworth 2017), particularly in the cotton industry, the legacy of which can still be seen in the industrial architecture of many towns and cities in this region. Quarry Bank Mill in Cheshire is one of the best-preserved textile mills from this era and is a Grade II listed building (National Trust 2019a) (Fig. 11 Looms, Quarry Bank Mill, Manchester). The mill and estate were given to the National Trust in 1939 even though it continued its production until 1959. Once production ceased, the National Trust also acquired Quarry Bank House and the surrounding gardens. Today, parts of the mill are still operational and visitors can see the looms and

Fig. 10 The Cloisonné Art Museum of China, Beijing Enamel Factory Co. Ltd.

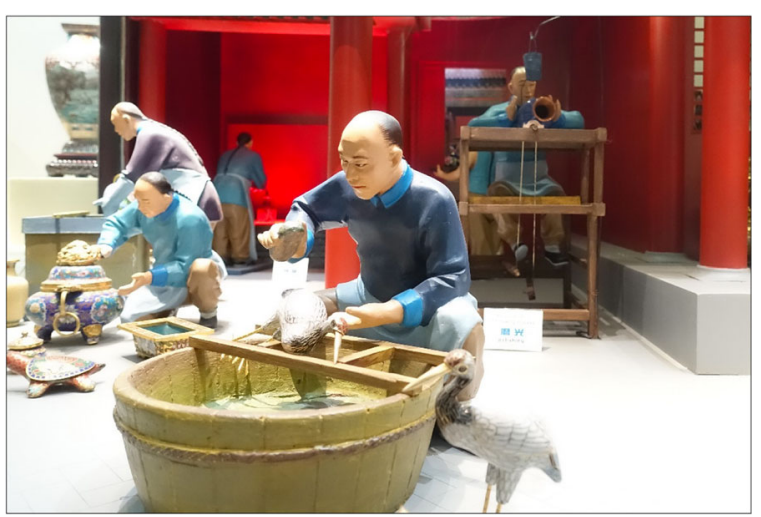




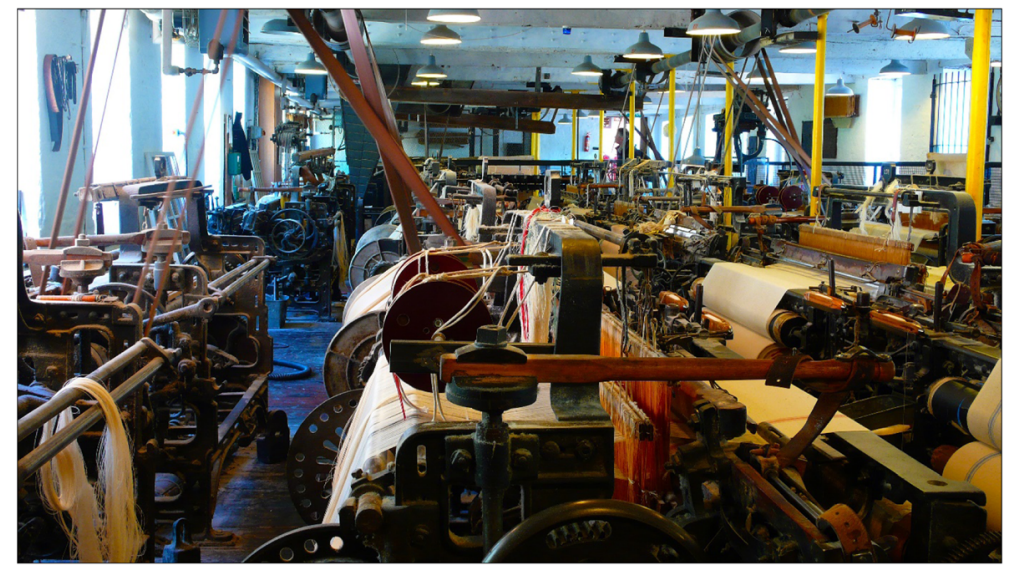

Fig. 11 Looms, Quarry Bank Mill, Manchester

other machinery in action, in a manner similar to the 'living museum' visited in China. However, unlike the examples in China, Quarry Bank does not produce goods as the looms are only operated for demonstration purposes. The mill museum also has an immersive audio-visual experience, where visitors are able to see the types of work formerly carried out in the mill and to learn about the social history of the site and those who worked there.

A walking tour of Manchester, the UK's second largest city, introduced the Chinese team to the industrial heritage of the north of England. Manchester was a key site of the Industrial Revolution, with a rapid increase in the number of factories. This placed the city at the heart of technological innovation and advanced production techniques in the 18th and 19th centuries, particularly in relation to the cotton industry. The architecture of the city still demonstrates its importance during that period, both nationally and on the global stage. During the twentieth century there was a decline in Manchester's industrial importance, prompting a depression with worsening socio-economic conditions. However, from the 1990s onwards, Manchester's position as a thriving cultural city saw significant investment that revitalised many areas and once again raised its profile nationally and internationally. Manchester, with the largest concentration of students in Europe, due to its two major universities and a large medical school, is again a major centre for research, innovation and technological development.

A visit to Liverpool, also in the northwest of England enabled the group to gain an understanding of cultural heritage regeneration. Liverpool was a major port during the Industrial Revolution. Its success was built on trade, due to its location on the River Mersey where it meets the Irish Sea, as well as (as we learned during a tour of the original Old Dock) a technological innovation related to the dock's introduction of sea doors, which speeded up the loading and unloading of cargo ships. The city grew as a major trading and emigration port between the 18th and 20th centuries, with its architecture reflecting its importance in building the British Empire. Six areas within the historic centre of the city have been granted UNESCO 
World Heritage Centre status, including Albert Dock, Stanley Dock, and the Cultural and Merchants Quarters (Liverpool World Heritage, 2019) (Fig. 12 Albert Dock Regeneration, Liverpool).

A UK example that echoes the transformation from industrial to heritage site, which we saw at Shougang Park in China, is the Royal Albert Dock, a complex of warehouses and mercantile buildings that were transformed into cultural and retail venues during the 1980s (Royal Albert Dock 2019). The docks are now home to two significant cultural and heritage organisations, Tate Liverpool, part of the organisation that also operates Tate Britain, Tate Modern and Tate St. Ives (Tate Gallery 2019), and the Merseyside Maritime Museum and International Slavery Museum (National Museums Liverpool 2019). The docks are also home to a vibrant mix of shops, restaurants and bars, and serve as a venue for large events such as the Tall Ships Regatta and the Clipper Round the World Yacht Race (Albert Dock 2019).

The curator at The International Slavery Museum, located within the same building as the Maritime Museum, introduced the group to displays concerning the role of Liverpool in the international slave trade and the consequences and subsequent abolition of the trade. The social and cultural history of the UK is strongly represented in museums around the country, often at local and regional level and supported by government funds. Contested and discreditable periods in history, such as the UK's involvement in the global slave trade are also represented as it is considered important to acknowledge the impact such periods of history had upon the people involved and to illustrate the legacy of such trades and the lessons to be learned.

Liverpool is also a significant city due to it being the childhood home of the world-famous pop group The Beatles, who became internationally renowned in the 1960s and 1970s. The Cavern Club, located in the centre of the city, is one of the

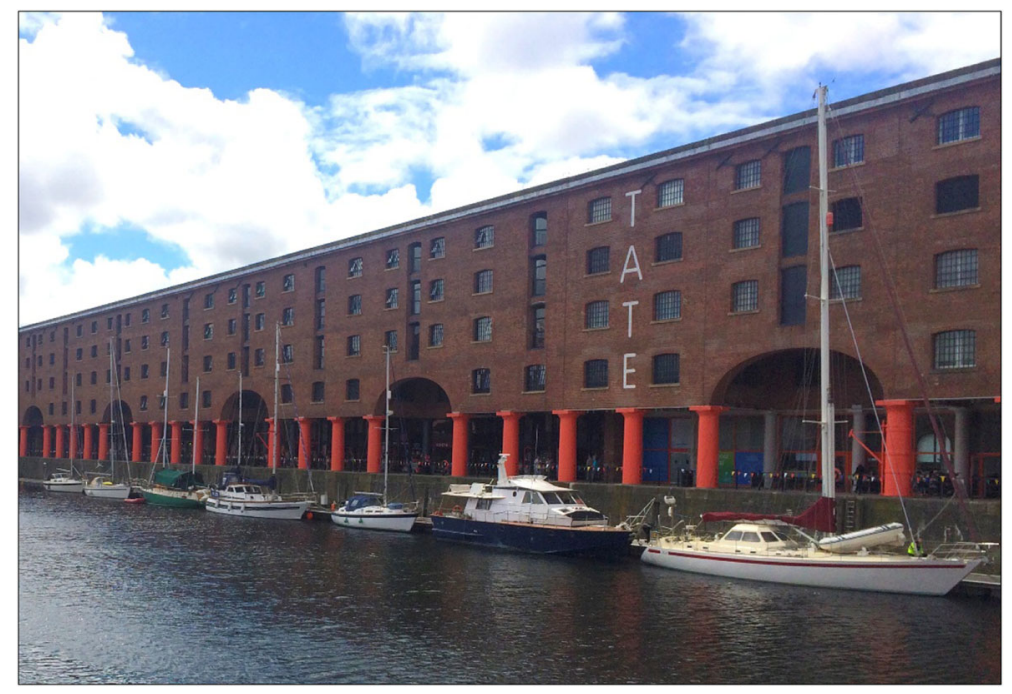

Fig. 12 Albert Dock Regeneration, Liverpool 
locations where the band performed and began their journey to fame. The original club closed and was converted into a railway ventilation system and underground parking garage, but in 1984 a new Cavern Club was opened on a site close to the original; it incorporates 15,000 bricks from the original building. Since reopening, the club has become a mecca for Beatles fans from around the world (Fig. 13 Cavern Club, Liverpool). This example demonstrates the potential for reinvigoration of an area based upon cultural heritage; in this particular case, the strong link to The Beatles who were, and remain, global cultural icons. By focussing upon the legacy of the band and their music, the club and surrounding area have developed into an ecosystem of businesses catering to international tourism.

Also during this visit to Manchester, a meeting was arranged between the Chinese team and a representative from Arts Council England, and to gain an understanding of how the organization works to support arts and culture in the UK, its funding mechanisms, its mechanisms for financial supporting projects, and the range of projects it covers.

In addition, Professor Nick Dunn provided us with a walking tour of central Manchester to view and hear about some of its most historically and culturally significant buildings.

\section{Lake District, June 2017}

The June 2017 visit took place at Lancaster University and the Lake District, Cumbria. The focus of this visit was cultural heritage, especially that of the British Romantic Period, which in many ways was a reaction to the industrialisation occurring just to the south in Manchester, Liverpool, and environs, during the nineteenth century. The centre of the British Romantic movement was the English Lake

Fig. 13 Cavern Club, Liverpool

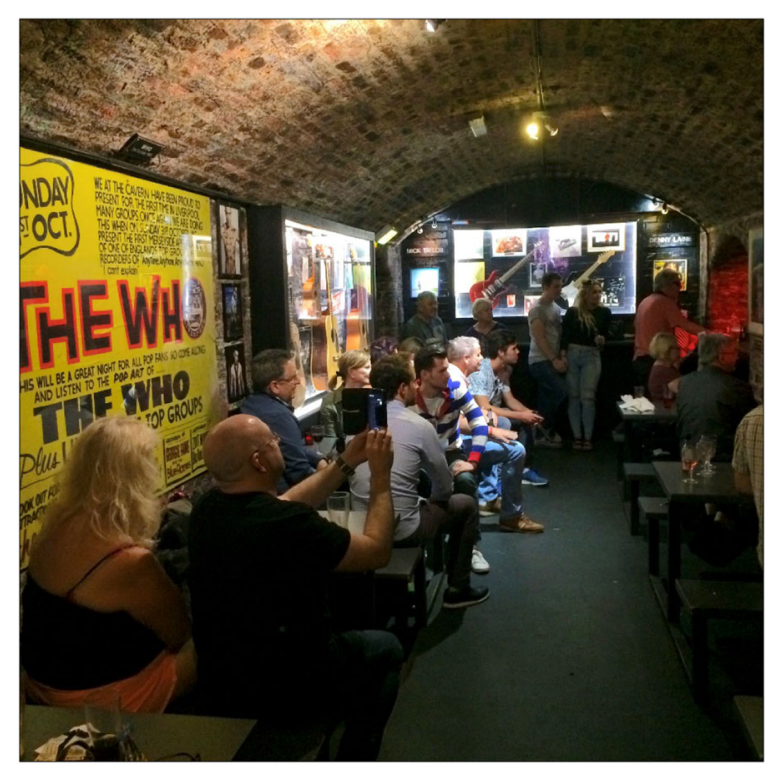


District, which today offers a range of cultural and natural attractions for visitors, including museums, significant houses related to the Romantic Period, and natural landscapes.

The Lake District is a UNESCO World Heritage Centre (UNESCO 2019a), designated for the beauty of its natural landscapes and its cultural significance, with a heritage of poetry, art and architecture. The British Romantic Period was largely a reaction to both rationalism and industrialism, both of which had significant impacts in the north of England. A key question the Chinese team wished to explore during this visit was "How can cultural heritage be protected whilst ensuring its relevance to contemporary life?"

The Lake District is home to a number of significant museums that represent key cultural figures and artistic movements that were not only influential in Cumbria, but internationally. Visits included Dove Cottage; Brantwood; Hill Top; and Blackwell, The Arts and Crafts House. These visits enabled the Chinese team to gain insights into how museums are operated in the region and to contrast the approaches to those currently being developed in China.

Dove Cottage in Grasmere is the former home of William Wordsworth, a key figure in British Romanticism (Fig. 14 Wordsworth's home, Dove Cottage, English Lake District).

The museum, cottage, tea rooms and shop are run by the Wordsworth Trust (Wordsworth Trust 2019). The cottage is a small house, with very small rooms which are furnished with original pieces. The lives of Wordsworth and his wife Mary are told of within the house and the Wordsworth museum, which at the time of our visit was undergoing significant expansion in order to develop the exhibition space and enlarge the café and gift shop. In the village of Grasmere, now a popular site for tourists with many cafés, restaurants and gift shops, lies a small church with a churchyard containing Wordsworth's grave. For the Chinese team, the

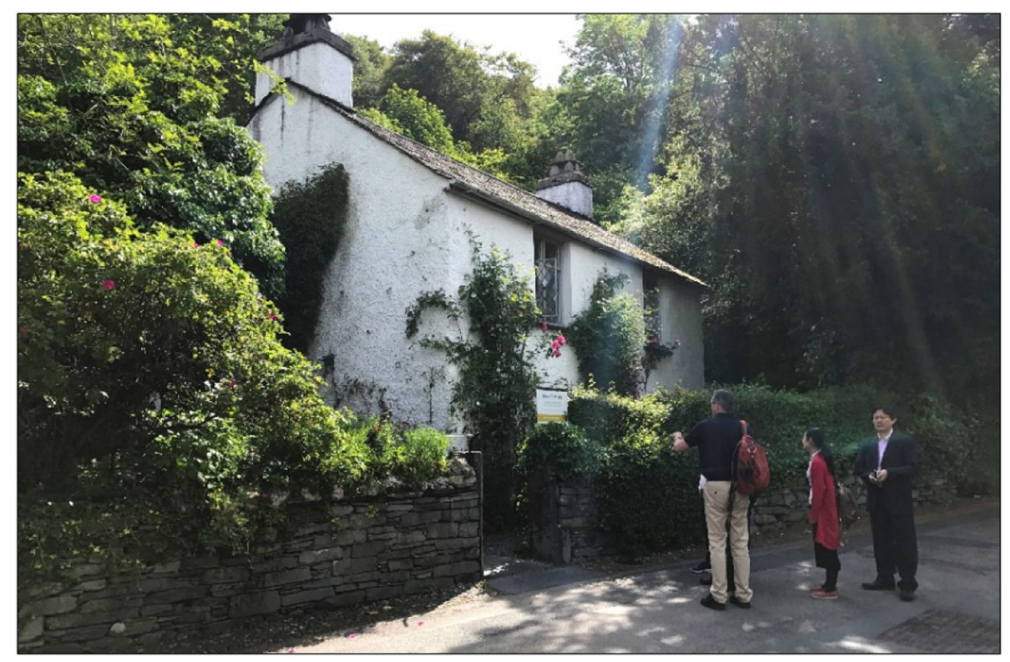

Fig. 14 Wordsworth's home, Dove Cottage, English Lake District 
unchanging nature of Dove Cottage was an interesting feature, and of particular interest was the enduring attraction for visitors. The Wordsworth Trust has been an important player in this sustainment, having been founded in 1891 when it took over the cottage and opened it to the public.

Brantwood was also visited. This is the former home of John Ruskin which, like Dove Cottage, is owned and run by a charitable trust, The Brantwood Trust, established in 1951 (Brantwood Trust 2019). Now open to the public as a museum, Brantwood also hosts exhibitions of contemporary art and hosts artists in residence, and, to bring in additional income, hosts weddings and events in the newly refurbished and much expanded restaurant. There is also a small gift and book shop, accommodation in an adjacent house designed by John Ruskin, and a large function room above the restaurant building.

Hill Top farmhouse, the former home of children's author, natural scientist and conservationist Beatrix Potter, is owned and operated by the National Trust and attracts large numbers of international tourists each year, particularly from Japan. Potter, an important cultural figure who is best known for her children's books such as Peter Rabbit, also owned Herdwick sheep farms in later life and cared deeply about sustaining the culture and heritage of the Lake District. Beatrix Potter was involved in the foundation of the National Trust and during her lifetime she acquired 5 farms and some 4000 acres of land with the express purpose of leaving these to the National Trust so they could be protected and enjoyed by the general public (Fig. 15 Traditional Spinning Wheel and Rocking Chair, Hill Top Farmhouse, English Lake District). The house and gardens are open to the public and attract a large number of visitors to the small village of Far Sawrey. It does not have many visitor facilities and is rather remote. Consequently, many visitors arrive on organised coach tours.

Blackwell, The Arts and Crafts House (Blackwell 2019) was the final visit in the Lake District. Located just outside the town of Windermere, it introduced the artistic responses to the Industrial Revolution, as experienced in the visit to Manchester and Liverpool. Blackwell was built in 1889 as the holiday home of Edward Holt, a brewery owner from Manchester. The house contains key examples of

Fig. 15 Traditional Spinning Wheel and Rocking Chair, Hill Top Farmhouse, English Lake District

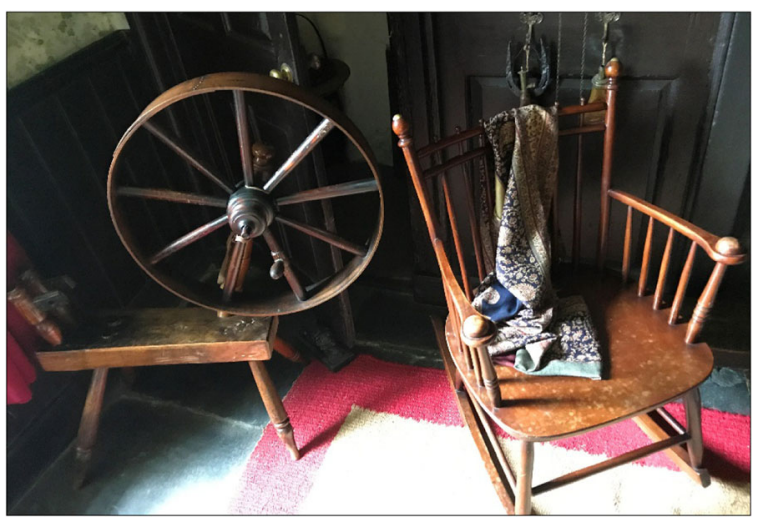


designs by Mackay Hugh Baillie Scott, a leading designer of the Arts and Crafts movement and is considered to be one of the finest remaining examples of the period in the country. After the house was sold by the Holt family it was used as a school and then offices, falling into disrepair, with many of its fine features covered over, before being purchased by the Lakeland Arts Trust which renovated the house and reopened it in 2001 as a museum and gallery. The house represents the antithesis of the Industrial Revolution that was embodied in the Arts and Crafts movement (Greensted 2010) and championed by the designer and writer William Morris, as well as key figures including John Ruskin, who favoured the handmade over machine-based production.

In addition to the house and museum visits, the Chinese team were given a boat tour of Lake Windermere and had a chance to sample English wines and products from The Lakes Distillery at a tasting evening at Storrs Hall overlooking the lake.

Tourism is a key industry in the Lake District, supporting many types of businesses from hotels and restaurants to visitor attractions and shops selling locally produced goods. Place-based goods inspired by Cumbria often embody the place through the materials from which they are made or the designs that represent the landscape and animals found within. One example is Herdy, a design-led company, established in 1997 by a couple with a background in design and interiors. The couple live locally and were inspired by the iconic Herdwick sheep, which are synonymous with the Cumbrian landscape (The Herdy Company 2019). One of the company's founders explained how they try to balance the development of the business with supporting the local economy and designing products that are attractive and represent the region. The company is very successful in the UK and has opened shops throughout Cumbria, but they are also seeking to develop the brand globally, which brings issues relating to responsible production and the challenges of branding and marketing products related to Cumbria in regions where the significance of the area is not widely known.

A different aspect to tourism in the region is the development of international audiences, which has seen significant growth in recent years. The Japan Forum (Japan Forum 2019) is a membership organisation whose aim is to promote international business through research exchange and collaboration. The Lake District attracts many tourists from Japan who visit the attractions, hotels and restaurants that are members of the forum. Japanese tourists were initially attracted to Hill Top because of the character Peter Rabbit, this attraction was then developed through the Japan Forum to include more venues and has resulted in an increase in forum membership and in greater numbers of Japanese visitors. For the China team this development illustrates that during the expansion of cross-cultural markets, cultural sensitivity is essential.

\section{London and Swindon, July 2018}

The purpose of this visit was to introduce the China team to the organisational and policy background of culture and heritage in the UK. Visits to the headquarters of Historic England and Historic England Archive and Library, and the National Trust, all based in Swindon, and the Heritage Alliance in London offered a broad 
introduction to the somewhat complex ecology of non-governmental heritage and cultural organisations in the UK.

Historic England (Historic Buildings and Monuments Commission for England) is an executive non-departmental public body of the UK Government which is sponsored by the Department for Digital, Culture, Media and Sport (DCMS). It is tasked with the protection of the historic environment by preserving and listing historic buildings and ancient monuments and providing advice to central and local government (Historic England 2019). The organisation was established in 1984 and operated until 2015 as English Heritage, at which point its name and function changed, becoming known as Historic England, with a new charity, officially called the English Heritage Trust taking the name of English Heritage. The two organisations now play different roles in the preservation of heritage. English Heritage is responsible for the stewardship and preservation of the National Heritage collection of more than 400 state-owned historic sites and monuments across England. It cares for and opens the properties to the public under a licence from Historic England that runs until 2023. Historic England is mainly funded by DCMS, it receives approximately $£ 86$ million per year and contributes around $£ 1$ million through its own income streams. It is the public body responsible for helping people care for, enjoy and celebrate England's historic environment, through the championing of historic sites, the identification and protection of the nation's heritage and by providing expertise at both the national and local levels. The organisation is also the UK government's statutory advice body and a statutory consultee on all aspects of the UK's historic environment and its heritage assets.

The headquarters of Historic England in Swindon are home to the Historic England Archive and Library, which holds over 60,000 books, journals and reports relating to the historic environment of England and over 12 million photographs, drawings, reports and publications ranging from architectural details and plans to archaeological sites throughout the country (Fig. 16 Historic England Archive, Swindon). A major project is being undertaken to digitise much of the collection in

Fig. 16 Historic England Archive, Swindon

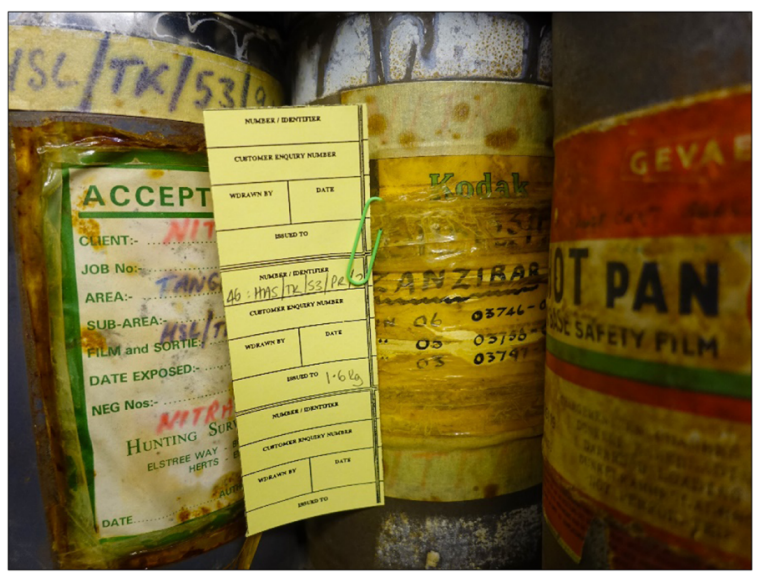


order to make it available online, which also opens up the potential for income generation through the licensing of images for reuse.

Another significant organisation responsible for the preservation of heritage in the UK is the National Trust (National Trust 2019b), whose headquarters are also in Swindon. The National Trust was established in 1895 by Octavia Hill, Sir Robert Hunter and Hardwicke Rawnsley and today it is one of the largest nongovernmental organisations responsible for the preservation and conservation of both built and natural heritage in the UK. The trust, whose motto is "for ever, for everyone", takes care of 780 miles of coastline, over 248,000 ha of land, over 500 historic houses, castles, ancient monuments, gardens and parks, and nature reserves, and close to one million objects and works of art throughout England. In recent years the trust has created a commercial organisation, which oversees the retail, catering and events throughout the country. A core method of fundraising is through membership, for which the trust has the largest membership of any organisation in the UK, and it has seen significant membership growth, from around 226,200 in 1970 to 4.8 million members in 2016/2017. Members enjoy free or reduced entry into National Trust properties and free car parking at their sites throughout the country, as well as regular newsletters.

Properties and land are acquired through a variety of methods, but predominantly through personal bequests and gifts, sometimes in lieu of significant death duties or estate tax.

Representatives from the National Trust offered insights into how the organisation operates and how it preserves cultural heritage. A key theme of the visit was the nature of volunteer work and the importance of this to the trust, with over 65,000 volunteers giving over 4.7 million hours of their time during 2016/2017. Volunteers engage in a wide range of activities, including house and property guides, gardeners, countryside rangers, researchers, trainers, translators, and events organisers. This approach differs greatly to that found in China, where volunteering within heritage organisations is not a widely recognised method of engagement and operation.

In the UK a range of non-governmental organisations care for the wide array of cultural heritage, including museums, galleries, historic monuments and houses, landscapes and industrial sites, many of which are quite small and rely upon volunteers to operate. These various organisations are represented by the Heritage Alliance (Heritage Alliance 2019), provides 'one voice' on their behalf to the government. The Heritage Alliance is a membership organisation that has become the largest coalition of heritage interests in the UK. The organisation represents over 100 independent organisations, from the National Trust, English Heritage, Canal and River Trust, to smaller specialist bodies representing independent owners, volunteers, funders and educationalists. It was founded in 2002 as an umbrella body for heritage organisations, and it plays various roles, with a primary focus being advocacy. Through the identification of the consensus of member organisations, it responds to parliamentary business and formal consultations. The alliance also advocates on broader issues such as the importance of heritage to the country, and it seeks to influence legislation, policy and guidance. Its other roles include information dissemination and sharing, the coordination and capacity building among members, and the organisation of various events such as projects and forums on heritage related subjects. 


\section{Key Insights from the China Exchange Visits to the UK}

The Manchester - Liverpool visits highlighted the following:

Industrial heritage - the UK played a key role in the Industrial Revolution and some of these sites are still operational as museums. The architecture of Liverpool and Manchester represents the history of the two intimately related cities in the industrialisation of Britain and Britain's international status as the centre of an empire. For Liverpool, this legacy has been recognised through it being awarded the UNESCO World Heritage Centre status for six areas around the city.

Urban renewal - in Liverpool the docks have been at the centre of urban renewal, with the opening of key cultural institutions such as Tate Liverpool and the Maritime Museum being the catalyst for the development. In addition, bars, restaurants and shops have added to the rich ecology in the area, making it an important area for tourism.

Cultural renewal - Liverpool's strong links to the Beatles have been the focus of renewal in the area surrounding The Cavern Club. We also saw attractions based upon 'personalities' in the Lake District, with the former homes of Ruskin, Wordsworth and Potter all being developed into visitor attractions.

'Living heritage' - The Lake District was of interest to the China team due to its strong focus on what they called 'living heritage', where tourists are still able to visit important locations, and life continues on the farms and in the tourist areas. This approach differs from that found in China, which the Chinese team referred to as 'dead heritage,' where there is a tendency to close off areas to visitors and remove residents in order to preserve heritage sites (Wang 2012). In China the preservation of heritage often means places become 'untouchable' and the sole source of industry in a tourist area, e.g. an historic walled city becomes focussed around hotels, restaurants, or the selling of tourist goods (Wang ibid.). There are also differing approaches to the contents of historic venues and houses in China and the UK, with the latter often keeping the interiors as they were, with furniture and objects in situ, enabling visitors to gain a glimpse of life during the historic period being represented. In China the contents of historic buildings are often removed and placed in the care of museums in order to preserve them.

Many locations in the Lake District are based around personalities, in particular Dove Cottage and Wordsworth; Brantwood and John Ruskin; Hill Top and Beatrix Potter. The lives and cultural contributions of these significant figures are both recognised and celebrated by allowing access to their homes, in addition to continuing their legacy through events such as literature festivals. This approach also enables organisations such as the Japan Forum to capitalise on cultural figures to attract tourists. However, there is also a need for an ecology to develop around the visitor attractions that support tourism, including infrastructure such as transportation and good road links, high quality restaurants and cafés, and hotels and shops. While this ecology has developed significantly in the Lake District in recent years, it still has issues relating to its location and relatively weak public transportation, its old and often over-burdened road systems, and the issues faced by small villages when they are host to increasing numbers of visitors; these include a lack of adequate hotels and restaurants, parking and so on. 
Visits to policy organisations highlighted key differences between the approaches adopted by the UK and China to cultural heritage. The UK seems to pay greater attention to tangible heritage, having not ratified the UNESCO Intangible Cultural Heritage directive (UK Government 2017), whereas China places significant emphasis on this. This might be attributed to the different definitions and positions of heritage in each country. In China, the government focuses on three primary goals: 1) to include cultural heritage within the creative industries in order to promote economic growth; 2) to preserve traditional cultures; and 3) to make cultural heritage serve as a public service.

We also saw the differences between approaches to volunteering in the UK and China. During the visits on this exchange, we saw that UK organisations such as the National Trust rely on volunteers to operate. Even in local museums, volunteers are often still required for their operation. This willingness to volunteer is strong a cultural feature in the UK, but is also a result of significant funding cuts to cultural venues by the UK government over the last decade (Museums Association 2018). In contrast, the Chinese government is investing significantly in museums and cultural heritage in order to increase the tourism market, nationally and internationally.

The landscape of cultural heritage organisations in the UK is somewhat confusing, as the China team expressed after the visit to the Heritage Alliance. A wide variety of organisations that are either independent or at arms-length from the UK government make it seem complex from the outside. Whilst this approach often results in duplicated effort and confusion as to who looks after what, it also ensures a high degree of independence from government and advocacy on behalf of smaller organisations with fewer resources.

\section{Conclusions}

From the visits to the UK and China, the research team identified themes that emerged from the interviews and observations made, the most pertinent of which are detailed below (Fig. 17 Design Ecologies Research Team, London July 2018).

Fig. 17 Design Ecologies Research Team, London July 2018

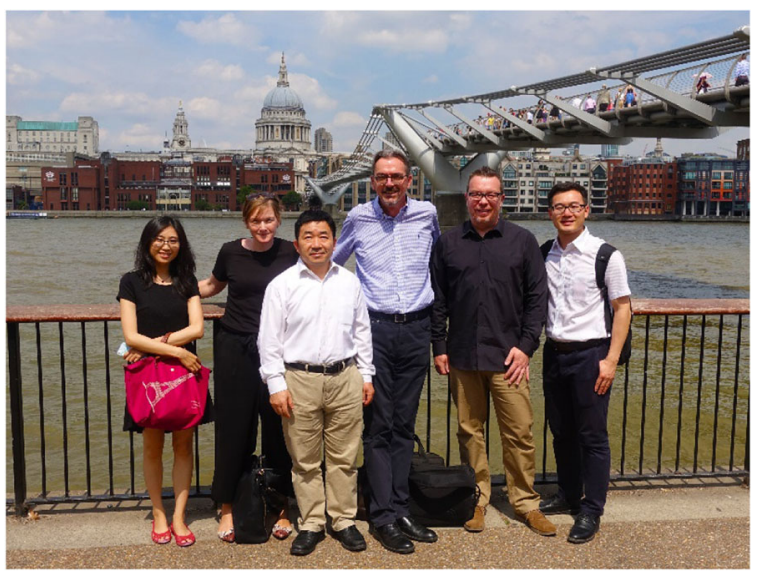




\section{Differing approaches towards 'living' heritage in China and the UK}

Insights gleaned from the UK and Chinese teams have highlighted key differences in approaches to heritage in the UK and China that might be categorised as predominantly 'bottom up' in the UK and 'top down' in China. The UK has a strong tradition of volunteerism, particularly in the heritage sector, where organisations such as the National Trust (National Trust 2019b) were created by a small number of people interested in saving and sharing the natural and built environment. Many cultural and heritage organisations in the UK rely on volunteers to operate and look after museums, historic houses and the natural landscape. This independence from government ensures the organisations' autonomy, enabling them to operate as they see fit, free from the constraints of policy and reliance on government funding. The China team characterised the UK's approach to the conservation and preservation of heritage as 'living heritage'. This approach was experienced by the Chinese team especially during the visit to the Lake District, where the teams visited a variety of museums run by large organisations that celebrate the heritage of the region. The Lake District achieved the status of UNESCO World Heritage Centre in 2017 (UNESCO 2019a) and is an area in which people still live and work. In China, such areas are often de-populated in order to preserve the heritage and become focussed specifically upon tourism (Wang 2008, 2012) whereas in the UK there are frequently ecosystems of tourism, heritage, and retail, along with communities that live and work in the locale. At Hill Top farmhouse, once owned by children's author Beatrix Potter (Lear 2008) and now owned and operated by the National Trust, visitors are able to walk around the house and gardens after paying an entry fee or showing their membership card. The National Trust is a charitable trust funded through donations, annual membership fees, entrance fees and a commercial arm that operates many gift shops, cafes and special events throughout the country. The trust also owns large areas of land and farms in the Lake District, acting as steward for the natural landscape whilst looking after and promoting the heritage of the area.

In contrast to the UK's 'bottom up' approach, China tends to operate in a way in which people are more removed from the experience of heritage, the preservation of which is funded by the government. Whilst this approach does encourage preservation, it can also create barriers that prevent interactions and connections between heritage and people. This approach was termed by the Chinese team 'dead heritage,' an approach which could potentially be less effective through focussing on preservation (protecting and saving) rather than conservation (keeping alive and maintaining). The Chinese approach is often to remove populations from within key heritage areas and resettle them elsewhere in order to develop heritage and cultural tourism in that area and preserve the landscape and built heritage sites.

In the Lake District there is a sense that conservation, use, and commerce are not necessarily in conflict. This is an area that seems to hold tensions in China, particularly in the current development of the tourism industry. 
Terminologies and tensions regarding the cultural and creative industries in the $U K$ and China

Both the UK and China teams recognised the differing terms used to describe and categorise the 'cultural' and 'creative' industries in China and the UK. The term 'creative industry' originated in the UK (British Council, 2019; Hewison 2014) and has been exported worldwide, as different countries have recognised the economic value of creative activities that can be as wide-ranging as computer games, creative technologies, fashion, film and TV, art, design and crafts. However, tensions have also been identified between the inclusion of traditional or heritage crafts within these industries. Such crafts are often produced to continue traditions for their own sake rather than for the valuing of such practices in economic and/or instrumental terms.

\section{Differing approaches to policy support of heritage and culture in China and the UK}

China's heritage and cultural institutions are predominantly governed and administered by the Chinese government at national, regional and local levels (Svensson 2016), whereas in the UK there is a mix of government owned and administered organisations, charitable trusts, and private organisations, which all seek funding from a variety of sources (Bagwell and Corry 2015). The China team also recognised the importance and significant value of volunteers within the UK's cultural heritage landscape. There is a rich tradition of volunteers within organisations such as the National Trust, which is a charity and relies on a mix of paid and unpaid workers to run and maintain many of its properties and natural landscapes. It would be interesting to compare and contrast this approach with China in future work to determine whether the nature of governmental policy inhibits such an approach.

\section{Ecologies of practice: an example of an effective 'design ecology'}

A particularly good example of a 'design ecology' is that of Jingdezhen, where in recent times the ceramics factories have changed - they have been repurposed since they were decommissioned. They are now home to a vibrant set of visitor attractions that still centre around ceramics. The ceramic makers now operate through a large number of interrelated and interdependent smaller enterprises that are more agile and offer more creative freedom than the former large government-owned factories. The whole complex works effectively as an 'ecology of practice' that involves specialist makers, production technologists, researchers, designers, artists, suppliers, retailers, market stall holders, tourists, hoteliers and restauranteurs.'

\section{Government investment in museums'}

During the UK team's visits to China we have seen evidence of significant investment in museums at national, regional and local scales. The importance of museums was also emphasised at the symposium held during the final visit, at the Chinese 
Academy of Social Sciences in March 2019, during which we were informed of the challenges of developing museums at a local scale. Small towns are expected to have a museum in order to develop their tourism market, but the collections usually relate to the local area and it is felt that such venues are more difficult to market to wider audiences. There are rich collections relating to the wide variety of ethnic groups in China, but this area has been less developed and is in the early stages.

In contrast, the UK has a rich history of small, often locally run and administered, 'local' museums that are often run and financed by local government, and that rely on the unpaid work of volunteers to stay open (Museums Association 2018). The UK model often focusses on objects and collections relating to the local community and place, which attracts domestic tourists, and they generally charge a low entry fee or are entirely free. This model may be of use in developing the relatively new Chinese 'local' museums.

On a national scale, museums in China are being invested in heavily by the government and they have been enjoying significant increases in visitor figures in recent years. The ability to promote and celebrate the rich history of the country through opening up collections and developing museum buildings is seen to be a key driver in the tourism economy, for both domestic and international tourists. The model being adopted in the development of museums in China, and the one that also informed their approach to cultural heritage and preservation, is based heavily on European museums and displays (Svensson, 2006).

An approach used within museums in China is what the teams termed the 'living museum' e.g. in the Hangzhou Arts and Crafts Museum. This approach, where skilled craftspeople pursue their work in studio environments within the museum, is one way of helping sustain traditional Chinese craft-making-practices. It also provides museum visitors with opportunities to see the process, to purchase craft pieces, and to appreciate the care, quality and skills of the craft makers. Potentially, it also raises the perceived value of such artefacts because firstly, the work that goes into their making can be better appreciated and secondly, the artefacts are of museum quality and many of them are displayed on the upper floors of the same building. This model tends to integrate retail and heritage craft activities, providing craft makers with opportunities to discuss their work with visitors. A basket maker in England reinforced the value of this approach, telling us that, by making the products at fairs and festivals, visitors are more likely to appreciate the work that goes into them and are, therefore, prepared to pay the relatively high prices charged for handmade products.

While there are positive aspects to this approach, there is also a need to be cautious. Craft makers may be regarded as part of the museum display to be stared at by visitors. In addition, this approach may result in the crafts and practices remaining the same, rather than evolving in line with society, which could potentially lead to the stagnation of heritage crafts.

\section{Differing approaches towards intangible cultural heritage in China and the UK}

China supports Intangible Cultural Heritage, through its adoption of the UNESCO Convention for the Safeguarding of the Intangible Cultural Heritage 
(Svensson 2016). This support is also inscribed into Chinese law and is overseen by the Association of Intangible Cultural Heritage Safeguarding which was established in 2013 and is administered by the Department of Culture.

In contrast, the UK tends to focus more on tangible cultural heritage, such as landscapes, historic buildings, museums, and galleries, and has not ratified the UNESCO ICH convention (UK Government 2017).

\section{Policy-related support in China and the UK}

For the Chinese government, efforts related to heritage are focussed upon the promotion of economic growth, the retention and preservation of traditional cultures, and the operation of key heritage locations as public services. Changes in government departments demonstrate the significance of this area, most notably with the merging of the Department of Culture with the Bureau of Tourism into the Department of Culture and Tourism. This demonstrates the shift towards the economic and cultural importance of the UNESCO Intangible Cultural Heritage programme in China.

The potential for design to contribute to the sustainment of traditional makingpractices

During the visits, the UK team identified particular areas where design may be able to contribute to the development and sustainment of cultural heritage and traditional making-practices. These include the potential for design visualisation of the interrelated and interdependent ecosystems of design and production that was observed-for example, in the repurposed Jingdezhen Ceramics Factory and related enterprises. The team observed that at Taoxichuan Creative Zone, design was making a considerable contribution to the creation of the artefacts, point of sale, branding and packaging. There is potential for this example to be explored further with different case studies, perhaps in tandem with the UK team's Living Design and Located Making projects (Gateway to Research 2019), which explore how design can contribute to the sustainment of small maker-enterprises in Cumbria, UK and in China.

Acknowledgements We would like to thanks the funding organizations - the AHRC in the UK and CASS in China - for supporting this project, as well as those who so generously gave their time to talk with us and show us their manufacturing and heritage facilities.

\section{Ethics and informed consent}

Institutional Ethics Approvals for this research were attained by the FASS and LUMS Ethics Committee, Lancaster University, along with respective approvals from Manchester Metropolitan University, Manchester and the Chinese Academy of Social Sciences, Beijing. All required consents were attained via the Project Information Sheet and Informed Consent Form, which are components of this ethically approved research. 


\section{Authors' contributions}

This paper is an output from a knowledge exchange project conducted between Professor Stuart Walker, Lancaster University, Professor Martyn Evans, Manchester Metropolitan University and Professor Wang Yanzhong and his colleagues at the Chinese Academy of Social Sciences in Beijing. The paper was jointly and collaboratively authored by SW, LM and ME with project input by WY. All authors read and approved the final manuscript.

\section{Funding}

We would like to thanks the Arts and Humanities Research Council - Newton Fund and the Chinese Academy of Social Sciences for providing financial support for this international knowledge exchange project.

\section{Availability of data and materials}

Not Applicable.

\section{Consent for publication}

Not Applicable.

\section{Competing interests}

The authors declare that they have no competing interests".

\section{References}

Albert Dock. 2019 Liverpool's historic Albert Dock available at: https://albertdock.com. Accessed 11 Sept 2019. Ashworth, W 2017. The industrial revolution: The state, knowledge and global trade, London: Bloomsbury Academic.

Bagwell, S; Corry, D 2015. The future of funding: Options for heritage and cultural organisations, Cultural Trends, 24 (1) pp.28-33 Available at https://www.tandfonline.com/doi/full/10.1080/09548963.2014. 1000583?casa_token=vfrBdiVtZ1oAoAAA:HPFvcztowwQ1Y6yNjYquWPVCNodes9Zm9ZYhi0aOwz9HRYTgKNrnA04N0HG8eB98wTM-byBY83N1BQ. Accessed 29 July 2019.

Baldwin, R 2019. EAEA16 Keynote Address: The Future of Globalisation, Asian Economic Journal, John Wiley \& Sons Australia, Ltd, Milton, Brisbane, Queensland, Vol. 33, No. 1, pps.3-12.

Baltic 2019 Baltic art Gallery. Available at https://baltic.art. Accessed 9 Sept 2019.

Blackwell, Arts and Crafts House. 2019. Available at https://www.blackwell.org.uk. Accessed 29 July 2019.

Brantwood Trust. 2019 Available at http://www.brantwood.org.uk. Accessed 29 July 2019.

British Council. 2019 Available at https://creativeconomy.britishcouncil.org/guide/what-creative-economy/. Accessed 29 July 2019.

Cominelli, F., and X. Greffe. 2012. Intangible cultural heritage: Safeguarding for creativity. City Cult Soc 3: 245-250.

Gao, J and $\mathrm{Wu}, \mathrm{B}$ 2017. Revitalizing traditional villages through rural tourism: A case study of Yuanjia Village, Shaanxi Province, China, Tourism Management, Elsevier, Amsterdam, Vol.63, pps. 223-233.

Gateway to Research. 2019. Available at https://gtr.ukri.org/projects?ref=AH\%2FN006615\%2F1. Accessed 23 July 2019. 
Greensted, M 2010. The Arts and Crafts Movement in Britain, Shire Books, Bloomsbury, London

Heritage Alliance. 2019 Available at https://www.theheritagealliance.org.uk. Accessed 23 July 2019.

Hewison, R 2014. Cultural Capital: The rise and fall of creative Britain London: Verso.

Historic England. 2019 Available at https://historicengland.org.uk. Accessed 23 July 2019.

Japan Forum. 2019 Available at http://www.kosuichihou.co.uk. Accessed 23 July 2019.

Jung, J., and S. Walker. 2018. Contextualizing culturally significant designs, products and practices. In Des Roots, ed. Evans Walker, Jung Cassidy, and Twigger Holroyd, 11-24. London: Bloomsbury.

Lear, L. 2008. Beatrix Potter. London: Penguin.

Liverpool World Heritage (2019) Available at: www.liverpoolworldheritage.com. Accessed 29 July 2019.

Museums Association. 2018. Available at: https://www.museumsassociation.org/museums-journal/news/ 13022018-local-authority-museums-at-risk-as-councils-in-crisis. Accessed 29 July 2019.

National Museums Liverpool. 2019. Merseyside Maritime Museum Available at: http://www.liverpoolmuseums.org.uk/maritime/.Accessed 29 July 2019.

National Trust. (a) 2019a Quarry Bank Mill Available at: https://www.nationaltrust.org.uk/quarry-bank. Accessed 11 Sept 2019.

National Trust. (b) 2019b Available at: https://www.nationaltrust.org.uk/features/about-the-national-trust. Accessed 22 July 2019.

Royal Albert Dock. 2019 Available at www.albertdock.com. Accessed 29 July 2019.

St Fagans Museum. 2019 Available at https://museum.wales/stfagans/. Accessed 29 July 2019.

Svensson, M 2006. In the ancestors' shadow: Cultural heritage contestations in Chinese villages. (working papers in contemporary Asian studies; no. 17). Centre for East and South-East Asian Studies, Lund University.

Svensson, M 2016. Evolving and contested cultural heritage in China: The rural heritage scape. In: Matsuda, a and Mengoni, L E (eds.) Reconsidering Cultural Heritage in East Asia, Pp. 31-46. London: Ubiquity press. DOI: https://doi.org/10.5334/baz.c. license: CC-BY 4.0.

Tate Gallery. 2019 Available at: www.tategallery.org.uk. Accessed 29 July 2019.

The Herdy Company. 2019 Availabe at: https://www.herdy.co.uk/?gclid=EAIaIQobChMIruz30aPa4wIVTLDtCh0tZQXGEAAYASAAEgI51PD_BwE. Accessed 29 July 2019.

UK Government. 2017. Convention for the Safeguarding of the Intangible Cultural Heritage: Written question - HL6360 [online], Available at: https://www.parliament.uk/business/publications/written-questionsanswers-statements/written-question/Lords/2017-03-27/HL6360. Accessed 4 July 2018.

UNESCO. (a) 2019a Lake District World Heritage Site, Available at https://whc.unesco.org/en/list/422/. Accessed 23 July 2019.

UNESCO. (b) 2019b China - Elements on the Lists of Intangible Cultural Heritage Available at: https://ich. unesco.org/en/state/china-CN?info=elements-on-the-lists. Accessed 29 July 2019.

Walker et al. 2018. Design Roots: Culturally Significant Designs, Products and Practices, ed. Walker, Evans, Cassidy, Jung, Twigger Holroyd, 11-24. London: Bloomsbury.

Wang, S.Y. 2008. A mirror with two sides - Heritage development and urban conservation in the Ancient City of Pingyao, China. Hist Environ 21 (3): 22-26.

Wang, S.Y. 2012. From a living city to a world Heritage City: Authorised heritage conservation and development and its impact on the local community. Int Dev Plann Rev.

Wordsworth Trust. 2019 Available at https://wordsworth.org.uk. Accessed 23 July 2019.

World Bank 2008. China's rapid urbanisation: Benefits, Challenges \& Strategies, The World Bank, Washington, DC, available at: https://www.worldbank.org/en/news/feature/2008/06/19/chinas-rapid-urbanisationbenefits-challenges-strategies. Accessed 9 July 2019.

World of Wedgwood. 2019 Available at https://www.worldofwedgwood.com. Accessed 29 July 2019.

Wu, J-X and He, L-Y. 2018. Urban-rural gap and poverty traps in China: A prefecture level analysis, Applied Economics, Routledge, Abingdon, Oxford, Vol. 50, No. 30, pps.3300-3314.

Zhang, Y 2019. Research on micro-marketing strategy of China's time-honoured brands, Advances in Economics, Business and Management Research, 76, 4th international conference on financial innovation and economic development.

\section{Publisher's Note}

Springer Nature remains neutral with regard to jurisdictional claims in published maps and institutional affiliations. 